\title{
Prolin-Rich Tyrosine Kinase 2 (PYK2) Expression and Localization in Mouse Testis
}

\author{
PAOLO CHIEFFI, ${ }^{1,2 *}$ MARCO BARCHI, ${ }^{3}$ SILVIA DI AGOSTINO, ${ }^{3}$ PELLEGRINO ROSSI, ${ }^{3}$ \\ DONATELLA TRAMONTANO,${ }^{4}$ AND RAFFAELE GEREMIA ${ }^{3}$ \\ ${ }^{1}$ Dipartimento di Medicina Sperimentale, II Università di Napoli, Naples, Italy \\ ${ }^{2}$ Dipartimento di Biologia e Patologia Cellulare e Molecolare, Università di Napoli "Federico II," Naples, Italy \\ ${ }^{3}$ Dipartimento di Biologia Cellulare e Sanità Pubblica, Sezione di Anatomia, Università di Roma Tor Vergata, \\ Rome, Italy \\ ${ }^{4}$ Facoltà di Scienze MM.FF.NN, Università del Sannio, Benevento, Italy
}

\begin{abstract}
Prolin-rich kinase 2 (PYK2) is a nonreceptor tyrosine kinase related to the focal adhesion kinase (FAK) p125 $5^{\mathrm{FAK}}$. PYK2 is rapidly phosphorylated on tyrosine residues in response to various stimuli, such as tumor necrosis factor- $\alpha$ (TNF- $\alpha$ ), changes in osmolarity, elevation in intracellular calcium concentration, angiotensin, and UV irradiation. PYK2 has ligand sequences for Src homology 2 and 3 (SH-2 and $\mathrm{SH}-3$ ), and has binding sites for paxillin and p130 ${ }^{\text {cas }}$. Activation of PYK2 leads to modulation of ion channel function, phosphorylation of tyrosine residues, and activation of the MAP kinase signaling pathways. Immunocytochemistry shows that PYK2 is present in mouse germinal and Sertoli cells (ser). Northern blot and immunoprecipitation analysis demonstrate that, among germinal cells, PYK2 is more abundant in spermatocytes (spc) and spermatids (spt); in addition, immunofluorescence analysis clearly shows that the diffuse cytoplasmic localization of PYK2 changes in a specific cellular compartment in spt and spermatozoa. Mol. Reprod. Dev. 65: 330-335, 2003.

(c) 2003 Wiley-Liss, Inc.
\end{abstract}

Key Words: spermatogenesis; focal adhesion kinase; phosphorylation

\section{INTRODUCTION}

The activation of protein-tyrosine kinases (PTKs) is one of the most common signal transduction mechanisms directly coupled to receptor activation by external signals. The PTKs that do not span the plasma membrane (the so-called nonreceptor PTKs) have been classified into different subclasses (subfamilies) (Robinson et al., 2000).

Protein tyrosine kinases have been well documented to be involved in the regulatory pathways in the cellular proliferation and differentiation (Dimecky et al., 1990). Some of the PTKs are involved in the spermatogenesis (Sorrentino et al., 1991; Yoshinaga et al., 1991), which is a well characterized developmental process from spermatogonia (spg) to mature sperm, providing an useful model systems to clarify the gene expression in cellular proliferation and differentiation (McCarrey, 1993).
Prolin-rich tyrosine kinase 2 (PYK2, also known as CAKB, RAFTK, FAK2, and CADTK) is a nonreceptor PTK that is closely related to the focal adhesion kinase (FAK) p125 ${ }^{\text {FAK }}$ (Avraham et al., 1995; Lev et al., 1995). The cDNAs of the protein have been cloned from rat (Sasaki et al., 1995), mouse (Avraham et al., 1995), and human (Lev et al., 1995; Herzog et al., 1996). PYK2 and FAK share a similar structural organization with a tyrosine kinase domain flanked by noncatalytic domains at both $\mathrm{N}$ - and $\mathrm{C}$-termini. Both proteins have ligand sequence for Src homology 2 and 3 (SH-2 and SH-3) domain (Dikic et al., 1996) but do not have SH-2 and SH-3 domains themselves. It has been shown a constitutive association of PYK2 with paxillin (Li and Earp, 1997) and $\mathrm{p} 130^{\text {cas }}$ (Astier et al., 1997), two other FAKbinding proteins (Guan, 1997). PYK2 mRNA is less evenly expressed in a variety of organs than FAK mRNA (Sasaki et al., 1995). PYK2 is highly expressed in the central nervous system (Lev et al., 1995), in cells and tissue derived from hematopoietic lineages (Dikic et al., 1998), and in the prostatic epithelium (Stanzione et al., 2001; Picascia et al., 2002).

PYK2 is activated by various extracellular signals including inflammatory cytokines, TNF- $\alpha$, angiotensin, UV irradiation, changes in osmolarity, and increase in intracellular calcium concentration. PYK2 can function as an upstream mediator of the JNK signaling pathway via a mechanism currently unknown (Tokiwa et al., 1996). In addition, PYK2 can activate the Ras-MAPK signaling pathway by both direct and indirect recruitment of the adapter protein Grb2 and Shc (Dikic et al., 1996), appearing to be a key mediator of intracellular signaling linking a variety of extracellular stimuli (Guo et al., 1998). Thus, PYK2 could be the cross step linking the variously activated pathways controlling cell growth and differentiation.

\footnotetext{
Grant sponsor: MURST
}

*Correspondence to: Paolo Chieffi, MD, PhD, Dipartimento di Biologia e Patologia Cellulare e Molecolare, via Pansini, 5 (80131) Napoli, Italy. E-mail: Paolo.Chieffi@unina2.it

Received 4 December 2002; Accepted 3 February 2003

Published online in Wiley InterScience (www.interscience.wiley.com) DOI 10.1002/mrd.10297 
In the present paper, we analyze the expression, the localization, and the activation of PYK2 in mouse testis. The results reported in this study indicate the presence of PYK2 in the germinal epithelium suggesting its potential role in male germ cell proliferation and differentiation.

\section{MATERIALS AND METHODS Preparation of Testicular Cells}

Spermatocytes (spc) and spermatids (spt) cells were prepared from CD1 mice (Charles River, Italy) as previously described (Sette et al., 1999). Briefly, after dissection of albuginea membrane, testes were digested for $15 \mathrm{~min}$ in $0.25 \%(\mathrm{w} / \mathrm{v})$ collagenase (type IX, Sigma Chemical Corporation, St. Louis, MO) at room temperature under constant shaking. Digestion was followed by two washes in minimum essential medium (Life Technologies, Inc., Paisley, UK), hence seminiferous tubules were cut in pieces using a sterile blade and further digested in minimum essential medium containing $1 \mathrm{mg} / \mathrm{ml}$ trypsin for $30 \mathrm{~min}$ at $30^{\circ} \mathrm{C}$. Digestion was stopped by adding $10 \%$ fetal calf serum and the released germ cells were collected after sedimentation (10 min at room temperature) of tissue debris. Germ cells were centrifuged for $13 \mathrm{~min}$ at $1,500 \mathrm{rpm}$ at $4^{\circ} \mathrm{C}$ and the pellet resuspended in $20 \mathrm{ml}$ of elutriation medium $(120.1 \mathrm{mM}$ $\mathrm{NaCl}, 4.8 \mathrm{mM} \mathrm{KCl}, 25.2 \mathrm{mM} \mathrm{NaHCO}, 1.2 \mathrm{mM} \mathrm{MgS}_{4}(7$ $\mathrm{H}_{2} \mathrm{O}$ ), $1.3 \mathrm{mM} \mathrm{CaCl}_{2}, 11 \mathrm{mM}$ glucose, $1 \times$ essential amino acid (Life Technologies, Inc.), penicillin, streptomycin, $0.5 \%$ bovine serum albumin (BSA). Germ cells at pachytene spc, and spt steps were obtained by elutriation of the unfractionated single cell suspension as described previously (Meistrich, 1977). Homogeneity of cell populations, ranged between 80 and $85 \%$ (pachytene spc) and 95\% (spt), was routinely monitored morphologically. Mature spermatozoa were obtained from the cauda of the epididyms mature mice as described previously (Sette et al., 1997). Spg and Sertoli cells (ser) were obtained from prepuberal mice as previously described (Grimaldi et al., 1993; Rossi et al., 1993).

The human prostate cancer cell line PC3 used in these studies were grown in Dulbecco Modified Eagle Medium supplemented with $5 \%$ fetal calf serum (Kaingn et al., 1979).

\section{Antibodies}

Antibodies polyclonal rabbit anti-PYK2 antisera \#600, \#602, and \#638 were kindly provided by Prof. Joseph Schlessinger and by Dr. Ivan Dikic and described previously (Lev et al., 1995; Dikic et al., 1998); polyclonal anti-PYK2 $\left[\mathrm{pY}^{402}\right]$ raised in rabbit (no. 44-618; Biosource International, Inc., Camarillo, CA).

\section{Immunocytochemistry}

Mouse testes rapidly removed and fixed in Bouin's fluid, were serially dehydrated in ethanol and cleared in xylene. For each paraffin embedded sample, $4 \mu \mathrm{m}$ serial sections, mounted on slides, were dewaxed in xylene, and brought through ethanols to deionized distilled water. Ten sections/animal/month were examined. The endogenous peroxidases were quenched by incubation of sections in $0.1 \%$ sodium azide with $0.3 \%$ hydrogen peroxide for $30 \mathrm{~min}$ at $22^{\circ} \mathrm{C}$; nonspecific binding were blocked by incubation with nonimmune serum (1\% Trisbovine albumin for $15 \mathrm{~min}$ at $22^{\circ} \mathrm{C}$ ).

All sections were pre-treated with $0.5 \%$ trypsin in $0.1 \%$ hydrochloric acid for $30 \mathrm{~min}$ at $37^{\circ} \mathrm{C}$ to unmask antigen. Before performing the immunohistochemical staining sections were further incubated in a $750 \mathrm{~W}$ microwave oven for $15 \mathrm{~min}$ ( 3 cycles of $5 \mathrm{~min}$ ) in $10 \mathrm{mM}$ buffered citrate, $\mathrm{pH} 6.0$, in order to complete antigen unmasking.

The standard avidin-biotin-peroxidase complex (ABC) procedure was used (Hsu et al., 1981). Anti PYK2 antibody (\#638) were utilized at a dilution 1:400. Control experiments were performed using the secondary antibody alone or preabsorbed the primary antibody with excess of the cognate peptide $\left(10^{-6} \mathrm{M}\right)$.

The peroxidase activity was developed with the use of a filtered solution of $5 \mathrm{mg}$ of $3-3^{\prime}$-diaminobenzideine tetrahydrochloride (dissolved in $10 \mathrm{ml}$ of Tris-buffer $0.05 \mathrm{M}, \mathrm{pH} 7.6$ ) and $0.03 \% \mathrm{H}_{2} \mathrm{O}_{2}$. For nuclear counterstaining, Mayer's hematoxylin was employed. Sections were mounted with a synthetic medium.

\section{Immunofluorescence}

Cells were spotted on poly-L-lisine-coated glass slides and fixed either at room temperature for $15 \mathrm{~min}$ in PBS containing $0.1 \%$ paraformaldheyde (PFA) or at $-20^{\circ} \mathrm{C}$ for 5 min in methanol acetone 1:1. PFA treated cells were permeabilized for 5 min in PBS containing $0.1 \%$ Triton $\mathrm{X}-100$. Fixed cells were incubated for $30 \mathrm{~min}$ at room temperature with $10 \%$ goat serum in PBS and after three washes with $1.5 \%$ goat serum in PBS, were incubated for $1 \mathrm{hr}$ at room temperature with either polyclonal PYK2 antibodies \#602 or \#638 (diluted $1: 200$ in $1.5 \%$ goat serum in PBS), as primary antibody. Following five washes (10 $\mathrm{min}$ in $1.5 \%$ goat serum in PBS), cells were incubated for $1 \mathrm{hr}$ at room temperature with cyanin 3-conjugate anti-rabbit IgGs (Chemicon, \#AP132C, diluted 1:400) as secondary antibody. After five more washes (10 min in PBS), slides were mounted in 50\% glycerol in PBS and immediately examined by fluorescence microscopy; to stain DNA, $0.1 \mathrm{mg} / \mathrm{ml}$ Hoechst dye (Sigma) was added to the first wash. Control experiments were performed using the secondary antibody alone or preabsorbed the primary antibody with excess of the cognate peptide $\left(10^{-6} \mathrm{M}\right.$ ) (data not shown).

\section{Sperm Preparation and Capacitation}

Uncapacitated caudal epidymal sperm collected from CD1, was accomplished by the method of Visconti et al. (1995). Then, washed sperm cells $\left(10^{6}\right.$ cells $\left./ \mathrm{ml}\right)$ were capacitated by adding to medium $\mathrm{Ca}^{2+}(2 \mathrm{mM})$, pyruvate $(1 \mathrm{mM})$, and BSA $(3 \mathrm{mg} / \mathrm{ml})$, followed by incubation at $37^{\circ} \mathrm{C}$ for 30 min under $5 \% \mathrm{CO}_{2}$ in air.

Capacitated mouse sperm $\left(10^{6}\right.$ cells $\left./ \mathrm{ml}\right)$ were incubated with ionophore A23187 (10 $\mu \mathrm{M}$, Sigma) for $1 \mathrm{hr}$ at 
$37^{\circ} \mathrm{C}$. The status of the sperm acrosome was determined by a staining technique (Feng et al., 1998). Briefly spermatozoa were air-dried on glass slides, fixed with 5\% paraformaldehyde in PBS $(\mathrm{pH} 7.4)$ and stained with 0.04\% Coomassie G-250 (in 3.5\% perchloric acid) for 5 min, and then rinsed with $\mathrm{H}_{2} \mathrm{O}$.

\section{Acrosome Staining Using Comassie Brillant Blue}

Acrosomal integrity was determined by a modified Comassie brillant blue staining technique (Moller et al., 1990). Spermatozoa were air-dried on polilisynated glass slides, fixed with $4 \%$ paraformaldehyde in phosphate buffer saline (PBS, 0.1 M, pH 7.4) for $15 \mathrm{~min}$, and washed once in PBS. The slides were stained for 5 min with $0.25 \%$ Commassie brillant blue made with $10 \%$ glacial acetic acid and $25 \%$ methanol in $\mathrm{H}_{2} \mathrm{O}$, and then rinsed with $\mathrm{H}_{2} \mathrm{O}$ and cover-slipped under 50\% glycerol in PBS. This method stains the acrosomal cap blue in acrosome-intact sperm but does stain the acrosome region in acrosome reacted sperm (Feng et al., 1997).

\section{RNA Extraction and Northern Blot Analysis}

Total RNA was extracted from cells and tissues using the Trizol Reagent (Gibco-BRL, Paisley, UK) and following the manufacture's instructions. Twenty micrograms of total RNA extracted were fractionated on a $1.2 \%$ agarose/formaldehyde gel and blotted onto nylon membrane (Hybond-N, Amersham, UK) with $10 \times$ SSC. The membrane was prehybridized at $42^{\circ} \mathrm{C}$ for $4 \mathrm{hr}$ in a solution containing $50 \%$ formamide, $3 \times \mathrm{SSC}, 60 \mathrm{mM}$ phosphate buffer (pH 6.8), 10 mM EDTA (pH 7.2), $0.2 \%$ SDS, and $5 \times$ Denhardt solution. Hybridization was carried out overnight under the same conditions with Pyk2-cDNA clone radiolabeled with $\left[\alpha^{32} \mathrm{P}\right]$ dATP by random examiner labeling (Feinberg and Volgelstein, 1984; Sambrook et al., 1989).

The membranes was washed once with $1 \times \mathrm{SSC}, 0.1 \%$ SDS at $42^{\circ} \mathrm{C}$ before autoradiography.

\section{Protein Extraction}

Tissues and cells were homogenized directly into lysis buffer containing $50 \mathrm{mM}$ HEPES, $150 \mathrm{mM} \mathrm{NaCl}, 1 \mathrm{mM}$ EDTA, $1 \mathrm{mM}$ EGTA, $10 \%$ glycerol, 1\% Triton X-100 (1:2 weight/volume), $1 \mathrm{mM}$ phenylmethylsulfonyl fluoride (PMSF) $1 \mu \mathrm{g}$ aprotinin, $0.5 \mathrm{mM}$ sodium orthovanadate, $20 \mathrm{mM}$ sodium pyrophosphate, (Sigma), and clarified by centrifugation at $14,000 \mathrm{~g}$ for $10 \mathrm{~min}$. Protein concentrations were estimated using a modified Bradford assay (Bio-Rad, Melville, NY).

\section{Immunoprecipitation and Western Blot Analysis}

Fifty microliters of protein A-Sepharose (Amersham Pharmacia Biotech, Buckinghamshire, UK) were incubated with $5 \mu \mathrm{l}$ of rabbit anti PYK2 antibody (\#600) for $1 \mathrm{hr}$ at $4^{\circ} \mathrm{C}$, and subsequently incubated with $500 \mu \mathrm{g}$ of protein total lysates for $2 \mathrm{hr}$ at $4^{\circ} \mathrm{C}$. Immunoprecipitates were washed four times with HNTG (20 mM HEPES,
$15 \mathrm{mM} \mathrm{NaCl}, 0.1 \%$ Triton X-100, 5 or $10 \%$ glycerol) and boiled in Laemmli buffer (Tris-HCl, $\mathrm{pH} 6.8,0.125 \mathrm{M}$, SDS $4 \%$, glycerol $20 \%$, 2-mercaptoethanol $10 \%$, bromophenol blue $0.002 \%$ ) for 5 min before electrophoresis (Tokiwa et al., 1996). Immunoprecipitates were subjected to SDS-PAGE (7.5\% polyacrylamide) under reducing condition. After electrophoresis, proteins were transferred to nitrocellulose membrane (Immobilon Millipore Corporation); complete transfer was assessed using pre-stained protein standards (Bio-Rad, Hercules, CA). After blocking with TBS-BSA (25 mM Tris, pH 7.4, $200 \mathrm{mM} \mathrm{NaCl}, 5 \% \mathrm{BSA}$ ), the membrane was incubated with the primary antibody against PYK2 (\#600 or \#602, diluted 1:500) in TBS for $1 \mathrm{hr}$ (at room temperature). All the primary antibodies used were rabbit polyclonal IgG raised against the peptide sequence. Membranes were incubated with the horseradish peroxidase-conjugated secondary antibody $(1: 2,000)$ for $45 \mathrm{~min}$ (at room temperature) and the reaction was detected with ECL system (Amersham Life Science, Bucks, UK).

\section{RESULTS \\ Expression and Localization of PYK2 in the Mouse Testis}

Immunocytochemistry was performed on serial testis sections using antibody against $\mathrm{N}$-terminal region of PYK2 (\#638). The protein was found in the germinal epithelium in the cytoplasm of spg, spc, spt, and in ser (Fig. 1A). The antiserum used in this study fulfils the criteria of specificity. In particular, immunoadsorption tests revealed that the labeling was totally blocked preincubating antibody with $10^{-6} \mathrm{M}$ of the cognate peptide (Fig. 1B).

We evaluated PYK2 expression in various testis cells using Northern blot hybridization with PYK2 specific probe. PYK2 mRNA was expressed as a single band of $4.5 \mathrm{~kb}$ in germ cells during the progression from spg to spt, as compared with the prostatic PC3 cells positive control (Fig. 2). In the germinal epithelium cells, the transcript was more abundant in spc, spt, present in ser, and it was almost absent in the spg and interstitial cells (Fig. 2).

Immuprecipitation and Western blot analysis of whole mouse testis and cell extracts from fractionated adult testis cells showed a single product migrating as a $110 \mathrm{kDa}$ protein as compared with the prostatic PC3 cells positive control (Fig. 3). Among germ cells, it was present in spg, abundant in spc, spt, and spermatozoa. PYK2 protein was present in ser and almost absent in the interstitial cells (Fig. 3); the presence of a specific weak band in the interstitial extract cells is, probably, due to the ematopoietic cells contamination that express PYK2 protein (Dikic et al., 1998).

\section{Immunofluorescence Analysis of PYK2 in Mouse Germinal Cells}

The localization of PYK2 in germinal cells were investigated by immufluorescence analysis, using either polyclonal rabbit anti-PYK2 antisera \#602 or \#638. 


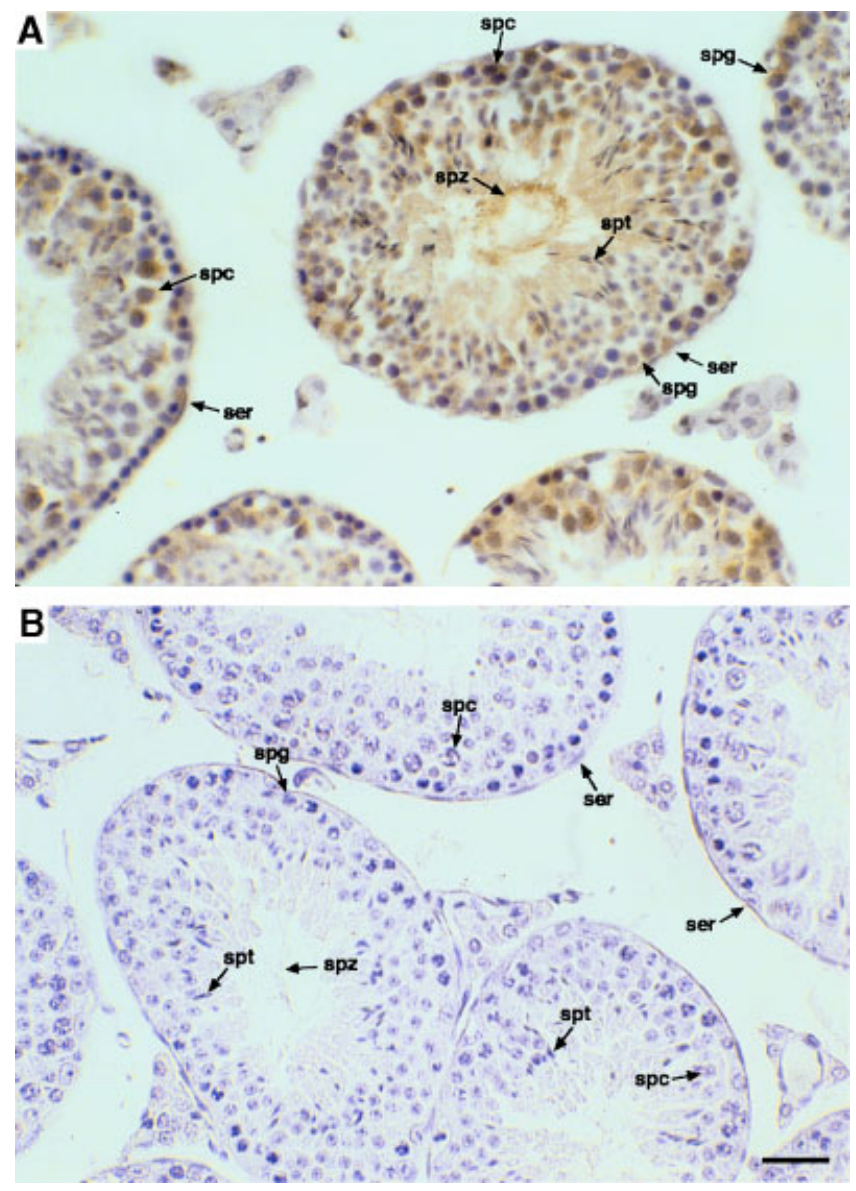

Fig. 1. A: Localization of the prolin-rich tyrosine kinase 2 (PYK2) protein in sections of adult mouse testis by immunocytochemistry. Representative seminiferous tubules showing staining in the cytoplasm of spermatogonia (spg), spermatocytes (spc), spermatids (spt), and Sertoli cells (ser). B: Control section using the antibody preadsorbed with the cognate peptide $\left(10^{-6} \mathrm{M}\right)$; symbols are as indicated above. $\mathrm{Bar}=50 \mu \mathrm{m}$.

The cells were fixed with methanol acetone and stained using PYK2 \#602 antibody. Stained cells showed a diffuse distribution of PYK2 protein with prevalent distribution in the cytoplasm region. In both $7-8$ days spg (Fig. 4A) old mice and adult mice spc (Fig. 4B), PYK2 immunostaining was observed in the cytoplasm with no localization in the nucleus. Similar results were obtained using either PFA or methanol acetone fixation with both antibody \#602 and \#638. Like in both spg and spc, in adult mice round spt, PYK2 showed a cytoplasmatic distribution (Fig. 4C). However, in round spt PYK2 staining was localized in a polar side of the cells which correspond in elongated spt to the acrosome region (Fig. 4D). In adult mice spermatozoa, PYK2 staining was localized in both acrosome region and tail (Fig. 4E). The specific acrosomal distribution was also demonstrated in Figure $4 \mathrm{~F}$ in which acrosome reacted spermatozoa were stained using PYK2 antibody \#638. In these cells, we observed a tail immunopositive staining but we never observed positive staining in the acrosomal region. Acrosomal integrity was determined

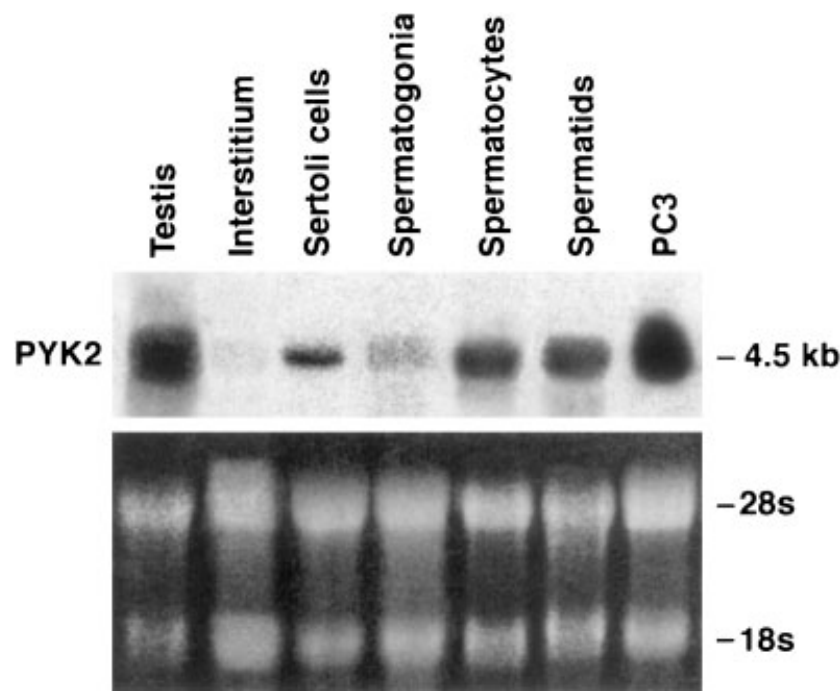

Fig. 2. Expression of Pyk2 mRNA in mouse testis. Northern Blot analysis of Pyk2 mRNA in adult mouse testis (lane 1), interstitial tissue (lane 2), ser (lane 3), in normal freshly isolated testicular cell populations (lanes 4-6), and PC3 cells positive control (lane 7). Each lane contained $20 \mu \mathrm{g}$ of total RNA. All blots were probed with Pyk2-cDNA. The integrity and relative abundance of RNA samples were determined by ethidium bromide staining of the filter (lower frame).

using Commassie brillant blue acrosome staining (data not shown).

\section{PYK2 Activation in Mouse Spermatozoa}

In order to investigate the activation status of PYK2, mouse spermatozoa were maintained in serum free medium (for $24 \mathrm{hr}$ ) and in presence of $\mathrm{CaCl}_{2}$. Then spermatozoa were treated with the ionophore A23187 (10 $\mu \mathrm{M}$, Sigma). A consistent activation of PYK2 (phosphorylation of the tyrosine 402) was detectable within 2.5 min after A23187 stimulation (Fig. 5) and declined thereafter. The phosphorylation status was confirmed observed the equal amount of PYK2 protein (Fig. 5).

\section{DISCUSSION}

This study was initiated to investigate the involvement in the testis of the nonreceptor tyrosine kinase PYK2 having a specific kinase activity on tyrosine residues (Avraham et al., 1995; Lev et al., 1995). PYK2

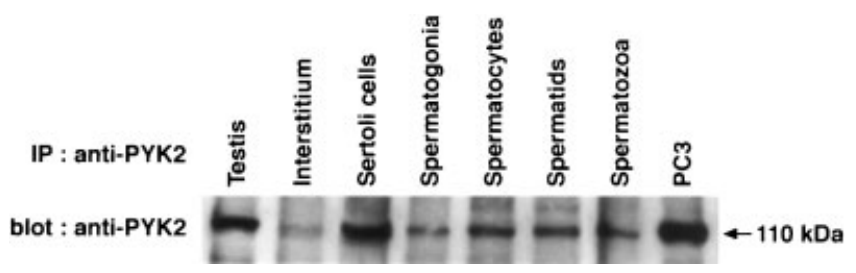

Fig. 3. The expression of PYK2 proteins in mouse adult testis (lane 1), interstitium (lane 2), ser (lane 3), normal mouse testis germ cells (lanes 4-7), and PC3 cells positive control (lane 8). Total lysates $(500 \mu \mathrm{g})$ for each sample were subjected to immunoprecipitation and immunoblot with antibody to PYK2 (\#600). A specific band was observed at $110 \mathrm{kDa}$ by comparison with co-migrating size markers. 

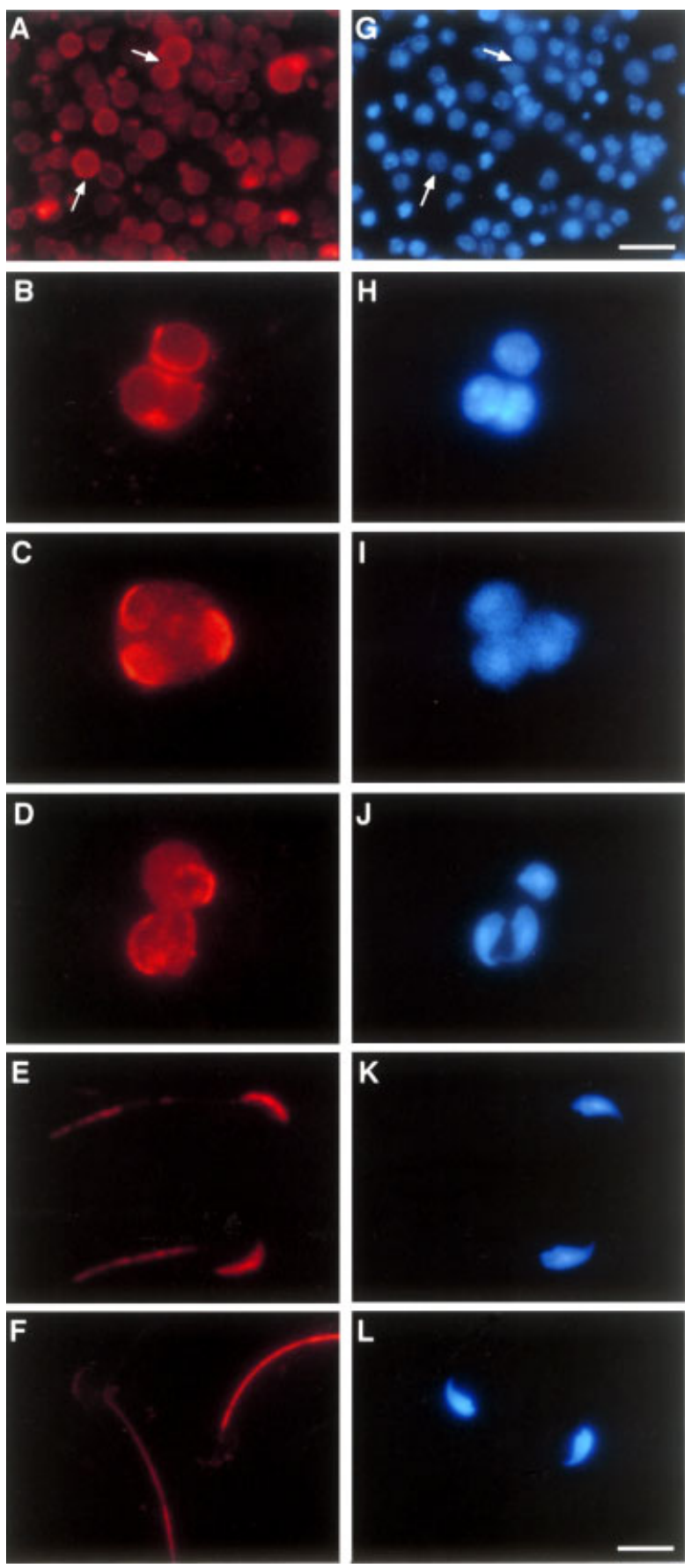

Fig. 4. Fluorescence microphotographs of (left panel) spg (A, arrows), spc (B), multinucleated round spermatid (C), elongated spt (D), spermatozoa (E), and acrosoma reacted spermatozoa (F) subjected to indirect immunofluorescence analysis with rabbit polyclonal anti PYK2 (\#638) antibody. All samples were also stained with Hoechst for the visualization of chromatin (right panel) spg $(\mathbf{G}$, arrows), spc $(\mathbf{H})$, round spermatid $(\mathbf{I})$, elongated spt $(\mathbf{J})$, spermatozoa $(\mathbf{K})$, and acrosoma reacted spermatozoa (L). Magnification: bar $=50 \mu \mathrm{m}(\mathrm{A}, \mathrm{G}) ; \mathrm{bar}=15 \mu \mathrm{m}(\mathrm{B}, \mathrm{C}, \mathrm{D}, \mathrm{E}, \mathrm{F}, \mathrm{H}, \mathrm{I}, \mathrm{J}, \mathrm{K}, \mathrm{L})$.

activation appears to be linked to neurotransmitters, growth factors, and inflammatory cytokines that induce alterations in calcium-dependent signaling pathways (Lev et al., 1995). PYK2 could thus take part in the

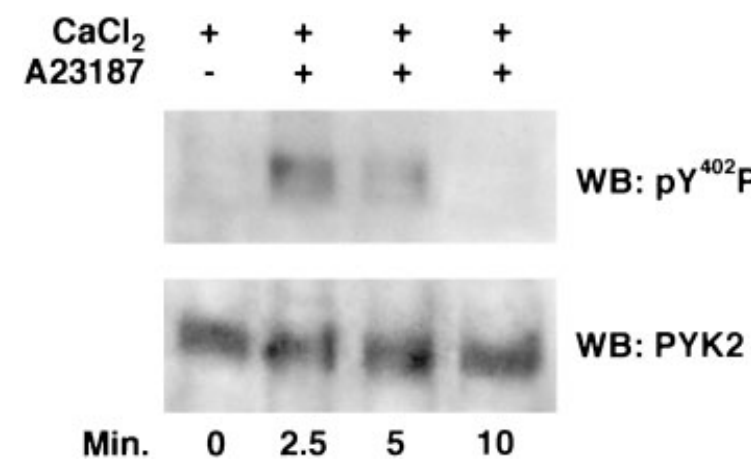

Fig. 5. Western blot detection of PYK2 proteins in the spermatozoa mouse extracts. The cells were incubated with $\mathrm{CaCl}_{2}$ and with the ionophore A23187 (10 $\mathrm{MM}$, Sigma Chemical Corporation, St. Louis, MO) at different time. Proteins (50 $\mu \mathrm{g}$ per lane) were resolved by SDSPAGE, transferred to nitrocellulose membranes and then incubated with antibody raised against phospho- $\mathrm{Y}^{402}$ PYK2 and PYK2 (\#600) protein. A specific band was observed at $110 \mathrm{kDa}$ by comparison with co-migrating size marker.

complex network of signal transduction pathways controlling both proliferation and differentiation. This may possibly occur via the activation of MAPK and/or JNK pathways (Lev et al., 1995; Dikic et al., 1996). It has been demonstrated that PYK2 associates with both microfilaments and microtubules, and play important roles for cellular movements such as membrane rufflings, cellular attachments, and cytokinesis (Aoto et al., 2000). It is well documented that PYK2 is highly expressed in brain (Avraham et al., 1995), hematopoietic (Dikic et al., 1998), and prostatic (Stanzione et al., 2001; Picascia et al., 2002) tissues, and in a variety of cell lines (e.g., PC12) (Lev et al., 1995). However, the localization and the role of PYK2 in testes has not been elucidated yet.

In the present study, we show that the expression of PYK2 varies in amount in the different cellular types of mouse testis. In fact, Northern blot and immunoprecipitation analysis demonstrate that PYK2 is more abundant in spermacytes and spt among germinal epithelium lineages, and in ser. In addition, the immunofluorescence analysis clearly show that the diffuse cytoplasmic PYK2 immunoreactivity present in spg and spc involves in a specific cellular compartment in round spt which correspond in elongated spt to the acrosome region; subsequently, in the mature spermatozoa PYK2 is detected with a specific localization in the acrosome region and in the tail. We could hypothesized a possible implication of PYK2 in the capacitation process of spermatozoa; in fact, it is well known that in human and mouse spermatozoa the calcium is necessary for the capacitation mechanism and that during this process it is present a strong increase of phosphorylation on tyrosine residues of many proteins (Visconti et al., 1995; Visconti and Kopf, 1998).

Different PTKs expressing in testis have been identified by molecular cloning. For example, c-kit, a transmembrane PTK gene, is well documented to be involved in germ cell development (Sorrentino et al., 1991; Yoshinaga 
et al., 1991). However, the relationship between PYK2 and the spermatogenesis has not been reported so far. To our knowledge, this is the first report showing the involvement of PYK2 in the spermatogenesis.

\section{CONCLUSIONS}

In conclusion, we have shown the involvement of PYK2 in mouse spermatogenesis by using different technical approaches. Our findings reported here support the idea that PYK2 activation could take part in a variety of cellular processes such as proliferation, differentiation, and spermatozoa capacitation. This study may give a clue to a better understanding the role of this tyrosine kinase product.

\section{ACKNOWLEDGMENTS}

This work was supported by MURST (ex 40\%, Prof. Raffaele Geremia) and Cofin-Prin (2002). We thank Prof. Joseph Schlessinger and Dr. Ivan Dikic for kindly providing PYK2 antibodies and probes.

\section{REFERENCES}

Aoto H, Mitaka T, Sasaki H, Ishino M, Mochizuki Y, Sasaki T. 2000. Association of cell adhesion kinase B (CAKB/PYK2) with cytoskeleton. Tumor Res 35:35-47.

Astier A, Avraham H, Manie SN, Groopman J, Canty T, Avraham S, Freedman AS. 1997. The related adhesion focal tyrosyne kinase is tyrosine-phosphorylated after B1-integrin stimulation in B cells and binds to p130cas. J Biol Chem 272:228-232.

Avraham S, London R, Fu Y, Ota S, Hiregowdara D, Li J, Jiang S, Pasztor LM, White RA, Groopman JE. 1995. Identification and characterization of a novel related adhesion focal tyrosine kinase (RAFTK) from megakaryocytes and brain. J Biol Chem 270:2774227551.

Dikic I, Tokiwa G, Lev S, Courtneidge SA, Schlessinger J. 1996. A role for Pyk2 and Src in linking G-protein-coupled receptors with Map kinase activation. Nature 383:547-550.

Dikic I, Dikic I, Schelssinger J. 1998. Identification of a new Pyk2 isoform implicated in chemokine and antigen receptor signaling. J Biol Chem 273:14301-14308.

Dimecky SM, Niederhuber JE, Desiderio SV. 1990. Specific expression of a tyrosine kinase gene, blk, in B lynphoid cells. Science 247:332336.

Feinberg AP, Volgelstein B. 1984. A technique for radiolabeling DANN restriction endonuclease fragments to high specific activity. Anal Biochem 137:266-267.

Feng H, Sandlow JI, Sandra A. 1997. Expression and function of the c-kit proto-oncogene protein in mouse sperm. Biol Reprod 57:194-203.

Feng H, Sandlow JI, Sandra A. 1998. The c-kit receptor and its possible signal transduction pathway in mouse spermatozoa. Mol Reprod Dev 49:317-326.

Grimaldi P, Piscitelli D, Albanesi C, Blasi F, Geremia R, Rossi P. 1993. Identification of $3^{\prime}, 5^{\prime}$-cyclic adenosine monophosphate-induciblenuclear factors binding to the human urokinase promoter in mouse Sertoli cells. Mol Endocrinol 7:1217-1225.

Guan JL. 1997. Role of focal adhesion kinase in integrin signaling. Int J Biochem Cell Biol 29:1085-1096.

Guo C, Zheng C, Martin-Padura I, Bian ZC, Guan JL. 1998. Differential stimulation of prolin-rich tyrosine kinase 2 and mitogen-activated protein kinase by sphingosine 1-phosphate. Eur J Biochem 257:403408.

Herzog H, Nicholl J, Hort YJ, Sutherland GR, Shine J. 1996. Molecular cloning and assignment of FAK2, a novel human focal adhesion kinase, to $8 \mathrm{p} 11.2$-p22 by nonisotopic in situ hybridization. Genomics 32:484-486.

Hsu SM, Raine L, Fanger H. 1981. Use of avidin-biotin-peroxidase complex $(\mathrm{ABC})$ in immunoperoxidase techniques: A comparison between $\mathrm{ABC}$ and unlabeled antibody (PAP) procedures. J Histochem Cytochem 29:577-580.

Kaingn ME, Narayan KS, Ohnuki Y, Lechner J, Jones LW. 1979. Establishment and characterization of a human prostatic cancer cell line (PC3). Invest Urol 17:16-23.

Lev S, Moreno H, Martinez R, Canoll P, Peles E, Musacchio JM, Plowman GD, Rudy B, Schlessinger J. 1995. Protein tyrosine kinase Pyk2 involved in $\mathrm{Ca}^{2+}$-induced regulation of ion channel and MAP kinase function. Nature 376:737-744.

Li X, Earp HS. 1997. Paxillin is tyrosine-phosphorylated by a preferentially associates with the calcium-dependent tyrosine kinase in rat liver epithelial cells. J Biol Chem 272:14341-14348.

McCarrey JR. 1993. Development of germ cell. In: Desjardins C, Ewing LL, editors. Cell of molecular biology of the testis. New York, NY: Oxford University Press. pp 58-89.

Meistrich ML. 1977. Separation of spermatogenic cells and nuclei from rodent testes. Methods Cell Biol 15:15-54.

Moller CC, Bleil JD, Kinloch RA, Wassarman PM. 1990. Structural and functional relationships between mouse and hamster zona pellucidaglycoproteins. Dev Biol 137:276-286.

Picascia A, Stanzione R, Chieffi P, Kisslinger A, Dikic I, Tramontano D. 2002. Pyk2 regulates proliferation and differentiation of prostate cells. Mol Cell Endocrinol 186:81-87.

Robinson DR, Wu YM, Lin SF. 2000. The protein tyrosine kinase family of the human genome. Oncogene 19:5548-5557.

Rossi P, Dolci S, Albanesi C, Grimaldi P, Ricca R, Geremia R. 1993. Follicle-stimulating hormone induction of steel factor (SLF) mRNA in mouse Sertoli cells, and stimulation of DNA synthesis in spermatogonia by soluble SLF. Dev Biol 155:68-74.

Sambrook J, Fritsch RF, Maniatis R. 1989. Molecular cloning: A laboratory manual. 2nd edition. Cold Spring Harbor, NY: Cold Spring Harbor Laboratory Press.

Sasaki H, Nagura K, Ishino M, Tobioka H, Kotani K, Sasaki T. 1995. Cloning and characterization of cell adhesion kinase $\mathrm{B}$, a novel protein-tyrosine kinase of the focal adhesion kinase subfamily. J Biol Chem 270:21206-21219.

Sette C, Bevilacqua A, Bianchini A, Mangia F, Geremia R, Rossi P. 1997. Parthenogenetic activation of mouse eggs by microinjection of a truncated c-kit tyrosine kinase present in spermatozoa. Development 124:2267-2274.

Sette C, Barchi M, Bianchini A, Conti M, Rossi P, Geremia R. 1999. Activation of the mitogen-activated protein kinase ERK1 during meiotic progression of mouse pachytene spermatocytes. J Biol Chem 274:33571-33579.

Sorrentino V, Giorgi M, Geremia R, Besmer P, Rossi P. 1991 Expression of the c-kit proto-oncogene in the murine male germ cells. Oncogene 6:149-151.

Stanzione R, Picascia A, Chieffi P, Imbimbo C, Palmieri A, Mirone V, Staibano S, Franco R, De Rosa G, Schlessinger J, Tramontano D. 2001. Variations of proline-rich kinase Pyk2 expression correlate with prostate cancer progression. Lab Invest 81:51-59.

Tokiwa G, Dikic I, Lev S, Schlessinger J. 1996. Activation of Pyk2 by stress signals and coupling with JNK signaling pathaway. Science 273:792-794.

Visconti PE, Kopf GS. 1998. Regulation of protein phosphorylation during sperm capacitation. Biol Reprod 59:1-6.

Visconti PE, Bailey JL, Moore GD, Pan D, Olds-Clarke P, Kopf GS 1995. Capacitation of mouse spermatozoa. I. Correlation between the capacitation state and protein tyrosine phosphorylation. Development 121:1129-1137.

Yoshinaga K, Nishikawa S, Ogawa M, Hayashi S, Kunisada T, Fujimoto T. 1991. Role of c-kit in mouse spermatogenesis: Identification of spermatogonia as a specific site of c-kit expression and function. Development 113:689-699. 